\title{
Morphometric Analysis of Gilgit River Basin in Mountainous Region of Gilgit-Baltistan Province, Northern Pakistan
}

\author{
Karamat Ali1,2*, Roshan M. Bajracharya1 ${ }^{1}$, Bishal Kumar Sitaula ${ }^{3}$, Nani Raut ${ }^{1}$, Hriday Lal Koirala4 \\ ${ }^{1}$ Department of Environmental Sciences and Engineering and Aquatic Ecology Center, Kathmandu University, Kathmandu, Nepal \\ ${ }^{2}$ Department of Environmental Sciences, Karakoram International University, Gilgit, Pakistan \\ ${ }^{3}$ Department of International Environment and Development Studies (Noragric), Norwegian University of Life Sciences (UMB), \\ Akershus, Norway \\ ${ }^{4}$ Central Department of Geography, Tribhuvan University, Kirtipur, Nepal \\ Email: *karamat03@gmail.com
}

How to cite this paper: Ali, K., Bajracharya, R.M., Sitaula, B.K., Raut, N. and Koirala, H.L. (2017) Morphometric Analysis of Gilgit River Basin in Mountainous Region of Gilgit-Baltistan Province, Northern Pakistan. Journal of Geoscience and Environment Protection, 5, 70-88. https://doi.org/10.4236/gep.2017.57008

Received: April 8, 2017

Accepted: July 11, 2017

Published: July 14, 2017

Copyright (C) 2017 by authors and Scientific Research Publishing Inc. This work is licensed under the Creative Commons Attribution International License (CC BY 4.0).

http://creativecommons.org/licenses/by/4.0/

\begin{abstract}
Watershed morphometric analysis of a basin is key to understand the hydrological processes. The Gilgit river basin is situated in the Hindu Kush and Karakoram Mountains of Pakistan. The provincial capital of Gilgit-Baltistan is located in the lower part of the basin. Morphometric evaluation of the Gilgit river basin was carried out to study its drainage characteristics and overall water resource potential. The entire Gilgit river basin has been divided into six sub-basins to calculate and analyze the selected morphometric parameters. Morphometric parameters have been classified into linear, aerial and relief aspect. Geographic Information System (GIS) provides a viable method to extract and evaluate the characteristic of hydrological response behaviour of the basin. In the present study the utilization of remote sensing data such as Thermal Topography Mission and Global Elevation Model (ASTER-GDEM), Sentinel 2A image, coupled with geological and field data into GIS environment for morphometric analysis of Gilgit Basin. The drainage area of the basin is $13,538 \mathrm{~km}^{2}$ and shows a dendritic drainage pattern for all sub-basins. The analysis reveals that drainage network of entire Gilgit river basin constitutes a $7^{\text {th }}$ order basin. Out of six sub-basins, Gilgit-Gahkuch (B1), Ishkoman (B2) and Phunder (B4) are $6^{\text {th }}$ order sub-basins. Yasin (B3) and Gupis (B5) are $5^{\text {th }}$ order sub-basins, while Bagrot (B6) is a $4^{\text {th }}$ order sub-basin. The Gilgit Basin drainage density value is $0.50 \mathrm{~km} / \mathrm{km}^{2}$, which indicates a well-drained basin. Morphometric parameters like stream number, order, length, bifurcation ratio, drainage density, stream frequency, elongation ratio, circularity ratio, form factor, relief and relative relief, slope, length of overland flow, ruggedness number, and hypsometric integral are calculated. The results indicate that the entire drainage basin area reflects youthful to early mature stage of
\end{abstract}


the fluvial geomorphic cycle and high potential of stream discharge which is dominated by high relief, rainfall, glacier and snow fed order streams.

\section{Keywords}

Drainage Morphometry, Gilgit Basin, Remote Sensing

\section{Introduction}

The natural structure of any drainage basin and its fluvial developments can be expressed in a quantitative way, and it can be analyzed through measurement of aerial, linear and relief aspect [1]. The quantitative expression of drainage basin morphometry was first presented by Horton (1945), pioneer of the field. After Horton's law, Strahler (1952) developed a stream order system, as fingertip tributaries are first order stream; two first orders combine to form a second order; two second orders form a third and so on. Drainage morphology of major and minor basin in many areas of the world, has been studied using conventional geomorphologic approaches [2] [3] [4].

Morphometric analysis has been used for quantitative measurement of a particular characteristic of an area tectonic activity, morphometric indices, erosional and depositional processes. Gardiner (1990) [5] indicated that in many studies, morphometric characteristics of drainage basins have been used to predict flood peaks and estimation of erosion rates. Morphometric parameters can be evaluated and calculated from the analysis of various drainage parameters such as basin area, perimeter, stream orders, length of drainage channels, drainage density, stream frequency, bifurcation ratio, elongation and circulation ratio, texture ratio, basin relief, slope ratio, ruggedness number and length of over land flow. Comprehensive morphometric assessment and analysis is very important for better understanding of hydrological processes [6] [7].

Over the last few decades, Satellite data and GIS techniques have been providing a viable platform for assessing topography and morphometric factors of a drainage system [8]. Morphometric analysis of drainage system is very helpful and viable in appraisal of water resource potential, watershed management and also for flood risk management. It is difficult to examine all drainage networks from field observation or through survey due to their extent throughout rough terrain over the vast areas especially in mountainous regions. Identification of drainage networks within basin or sub-basin can be achieved using advanced methods such as high resolution satellite imagery and Digital Elevation Models (DEMs) Advanced Space-born Thermal Topography Mission and Global Elevation Model (ASTER-GDEM), owing to its better accuracy particularly for hilly and complex terrain. ASTER DEM can be used to extract drainage networks, basin extent and delineation of micro-watershed boundaries [9].

Therefore, morphometric analysis of the watershed is important in understanding the hydrology of the watershed for sustainable use of natural resource as well 
as effective management of water induced disasters in mountainous areas. The present study aims at using the remote sensing and GIS technology to compute various parameters of morphometric characteristic of the Gilgit River Basin.

\section{Study Area Characteristics}

The Gilgit river basin (Figure 1) is bound between latitudes $35^{\circ} 80^{\prime} \mathrm{N}$ and $36^{\circ} 91^{\prime} \mathrm{N}$ and longitudes $72^{\circ} 53^{\prime} \mathrm{E}$ and $74^{\circ} 70^{\prime} \mathrm{E}$, located in the mountainous areas of Pakistan. Climate of the area is characterized by brief hot summers and cold winters. The average minimum and maximum temperature is $6.3^{\circ} \mathrm{C}$ and $19.4^{\circ} \mathrm{C}$. Annual relative humidity range from $23 \%$ and $55 \%$, while average rainfall is 4.24 inches. Hindu Kush and Karakoram Mountains are part of a complex of mountain ranges in the Centre of Asia. Hindu Kush and Karakoram comprised by of the group of parallel ranges with numerous spurs. The highest elevation of the studied area is $7669 \mathrm{~m}$ and lowest $1178 \mathrm{~m}$ above sea level. The area is characterised by steep peaks and steep slopes. The mountains are well known for occurrences of natural hazards such avalanches, landslides, rock falls, debris flows, flash flooding and Glacier Lake bursting (GLOF). Population of the Gilgit Basin is mostly concentrated in two cities, such as Gilgit and Gahkuch. Large and medium villages are situated throughout the area on rocky slopes. Intensive type of agriculture and livestock rearing is governed by the local economy while area is reliant on crops from southern parts of the country.

The Ghizer road and a part of Karakoram High (KKH) is located in the studied area, these roads heavily used by millions of people annually, which underlines its significance in connecting this rugged landscape to the mainland, as well as the people who live in the valleys of Gilgit watershed which is the only access to south parts of the country from the north side. Ghizer road represents the

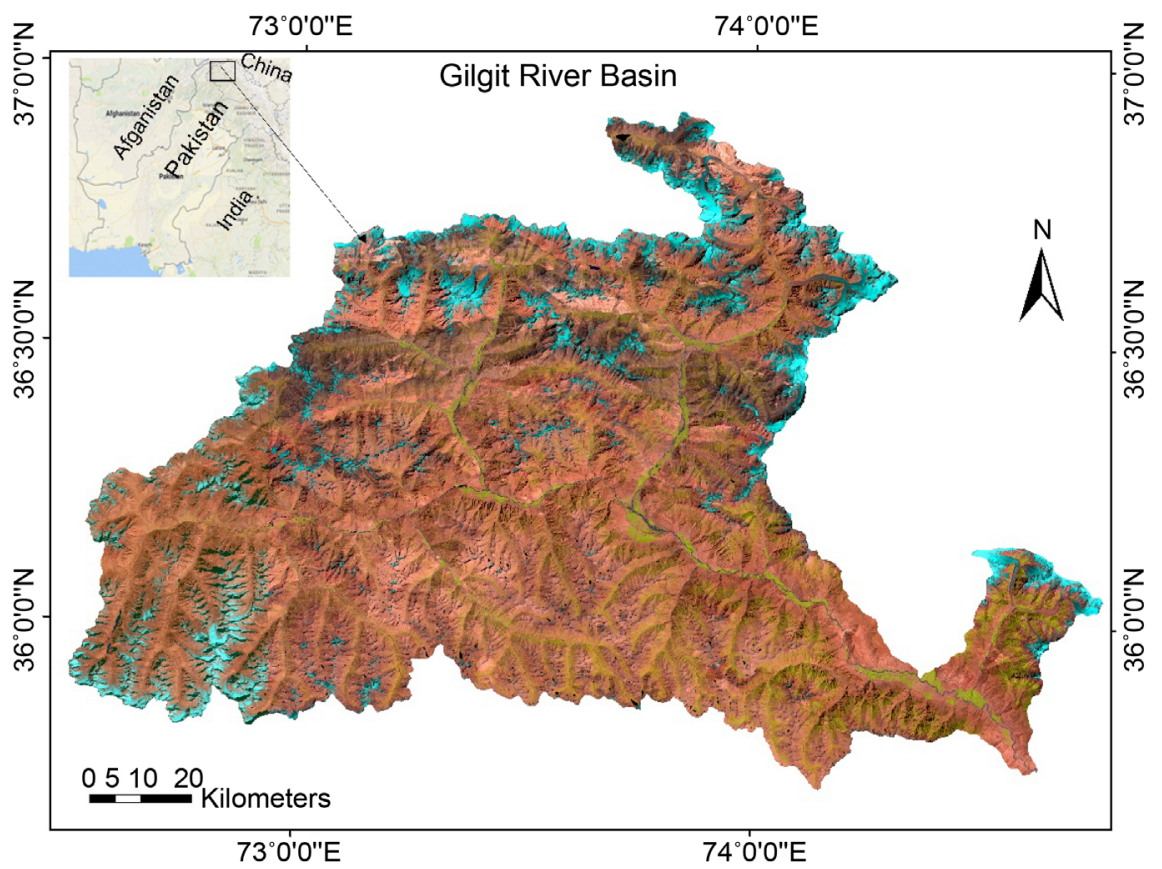

Figure 1. Location map of the Gilgit river basin. 
only highway connecting the Ghizer valley with Gilgit city and Chitral district of Khybar Pakhtunkhwa province of Pakistan (from east). Major and minor roads and several villages have been the subject of flash floods once or twice annually, especially in the monsoon season.

\section{Methodology}

In the current research, different types of data have been used which includes: 1) Advanced Spaceborn Thermal Topography Mission and Global Elevation Model (ASTER-GDEM) data, with $30 \mathrm{~m}$ spatial resolution. 2) Geological maps, 3) field data and reconnaissance. Arc ArcGIS 10.2.2 used to obtaining a deeper understanding of the drainage system in the study area. Terrain pre-processing has been used in the processing and creating the watershed basin of the study area. In Figure 2 present the methodological framework in a sequential order. The following characteristics being used to describe the entire six sub-basins for the morphometric analysis: 1) Linear Aspects: one dimension, 2) Aerial Aspects: two dimensions, 3) Relief Aspects: three dimensions. Linear drainage basin characteristics include; stream ordering, bifurcation ratio, total drainage network length, drainage frequency and drainage density. Aerial drainage basin characteristics include; drainage basin area, length, width, texture ratio, form factor, circulation ratio, elongation ratio, land of overland flow. Relief aspects parameters include; relief and relief ratio, relative relief, raggedness number, compactness coefficient, leminscate ratio and hypsometric integral [1] [3] [10] [11] [12].

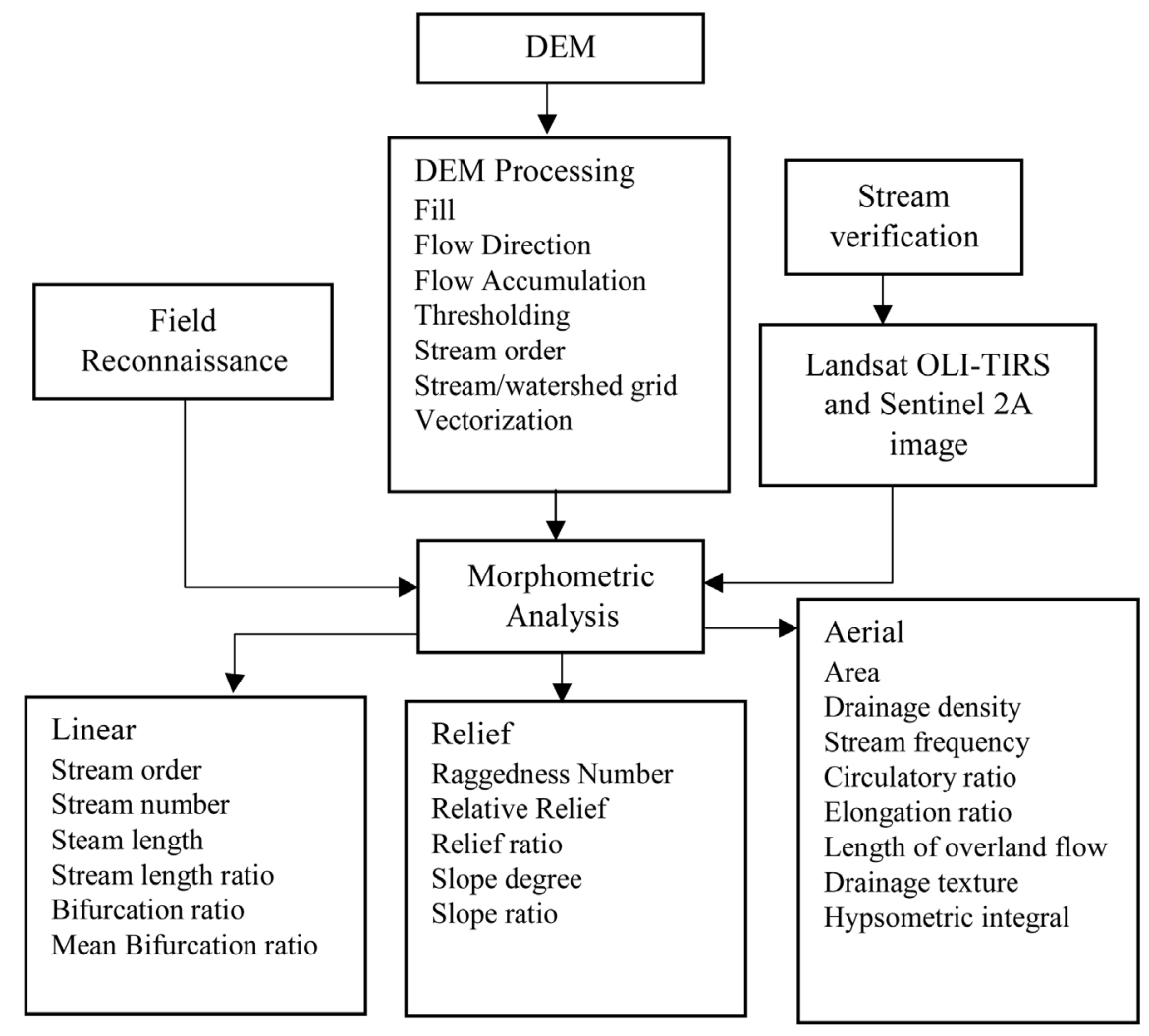

Figure 2. Methodological framework. 


\section{Results and Discussion}

The results of different morphometric parameters are listed in Table 1 and Table 2. Gilgit and it sub-basins exhibits dendritic drainage pattern. Physiographic characteristics of drainage basins like drainage density, stream orders, size, shape, relief, area and length of streams can be correlated with various hydrologic processes. Drainage basin morphology attempts to explain and predict the long-term aspects of basin dynamics resulting in morphological changes within the basin [12] [13] [14].

The total area of Gilgit basin is $13,538 \mathrm{~km}^{2}$ and areas of sub-basins are presented in Table 1 . The area of $\mathrm{B} 1$ is $3510 \mathrm{~km}^{2}$, which the largest basin among all six sub basins, while B6 is the smallest basin covered an area of $440.9 \mathrm{~km}^{2}$. The parameter of Gilgit basin is $857.4 \mathrm{~km}$ while sub-basins perimeters are presented in Table 1. The length of Gilgit basin is $172.7 \mathrm{~km}$ and length of subwatershed are shown in Table 1. The drainage pattern of Gilgit watershed is dendritic in nature and this pattern takes place in two stages such as at the first stage the streams by erosion of rocks goes downward and its tributaries are also increased in number, while in the final stage by capturing of smaller valleys by larger valleys. The relief and lithological character are mainly responsible for the development of dendritic pattern which are also reliant on geology and rainfall.

\subsection{Stream Order (U)}

Horton devised a quantitative method to analyzing drainage basins which have become a standard technique for presenting data on drainage basins. It is based upon a hierarchy of stream ordering which was revised by Strahler such as fingertip tributaries are first order stream, two first orders combine to form a second order, two second order form a third and so on. Drainage morphology of major and minor basin in many areas of the world have been studied using conventional geomorphologic approaches [1] [2] [15]. The number of streams $\left(\mathrm{N}_{\mathrm{u}}\right)$ in each order is presented in Table 1 for each sub-basins. Gilgit watershed is designated as a seventh-order basin. The regression trend between stream order and stream number reveal rapid decrease from lower order streams to higher order streams and negative correlation between low and high order stream (Figure 4). The maximum stream order frequency is observed in case of first order streams and then for a second order. Therefore, it is noted that there is a decline in stream frequency as the stream order increase and vice versa. The variation in stream order and frequency in the basin is observed because of the influence of physiographic and structural conditions. The river basin develops over the hard rocks, high relief, steep slope and impermeable surface material.

\subsection{Stream Number $\left(\mathrm{N}_{\mathrm{u}}\right)$}

Stream order $(\mathrm{U})$ refers to hierarchical link between the individual stream fragments than make up a drainage network. According to Horton's principle the number of streams is negatively correlated with the order such as stream number 
Table 1. Linear aspects of Gilgit river basin (GRB) and sub-watersheds.

\begin{tabular}{|c|c|c|c|c|c|c|c|}
\hline Parameters & B1 & B2 & B3 & B4 & B5 & B6 & GB \\
\hline Perimeter $(\mathrm{km})$ & 420.9 & 334.7 & 251.3 & 271.4 & 319 & 104.8 & 857.44 \\
\hline $\begin{array}{l}\text { Mean Basin } \\
\text { width (Wb) }\end{array}$ & 29.1 & 37.9 & 42.1 & 46.5 & 27.3 & 14.87 & 78.41 \\
\hline $\begin{array}{c}\text { Basin Length } \\
\text { (Lb) }\end{array}$ & 120.7 & 75.53 & 53.4 & 52.7 & 76.68 & 29.65 & 167.74 \\
\hline \multicolumn{8}{|l|}{$\begin{array}{l}\text { Number of } \\
\text { streams }\left(\mathrm{N}_{\mathrm{u}}\right)\end{array}$} \\
\hline N1 & 478 & 420 & 330 & 359 & 267 & 32 & 1886 \\
\hline $\mathrm{N} 2$ & 101 & 90 & 67 & 58 & 57 & 12 & 385 \\
\hline N3 & 21 & 22 & 15 & 13 & 13 & 3 & 87 \\
\hline N4 & 5 & 4 & 2 & 5 & 3 & 1 & 20 \\
\hline N5 & 2 & 2 & 1 & 2 & 1 & & 8 \\
\hline N6 & 1 & 1 & - & 1 & - & - & 3 \\
\hline N7 & - & - & - & - & - & - & 1 \\
\hline Total & 608 & 539 & 415 & 438 & 341 & 48 & 2390 \\
\hline \multicolumn{8}{|l|}{$\begin{array}{l}\text { Total stream } \\
\text { length }(\mathrm{Lt})\end{array}$} \\
\hline LT1 & 813.68 & 722.46 & 539.98 & 637.92 & 467.81 & 72 & 3253.84 \\
\hline LT2 & 451.76 & 363.97 & 260.92 & 215.39 & 271.88 & 38 & 1601.93 \\
\hline LT3 & 202.82 & 205.21 & 180.61 & 162.83 & 76.24 & 19 & 846.71 \\
\hline LT4 & 73.61 & 55.54 & 70.28 & 80.59 & 122.31 & 27 & 429.33 \\
\hline LT5 & 89.21 & 47.51 & 27.01 & 44.57 & 18.84 & - & 227.14 \\
\hline LT6 & 51.36 & 42.00 & - & 0.43 & - & - & 93.79 \\
\hline LT7 & - & - & - & - & - & - & 120. \\
\hline Total & 1682.44 & 1436.70 & 1078.80 & 1141.74 & 957.08 & 156 & 6572.75 \\
\hline \multicolumn{8}{|l|}{$\begin{array}{l}\text { Steam length } \\
\text { Ratio (Lr) }\end{array}$} \\
\hline Lr1 & - & - & - & - & - & - & \\
\hline Lr2 & 2.63 & 2.35 & 2.38 & 2.09 & 2.72 & 1.41 & 2.41 \\
\hline Lr3 & 4.69 & 2.31 & 3.09 & 3.37 & 1.23 & 2.00 & 2.34 \\
\hline Lr4 & 0.70 & 1.49 & 2.92 & 1.29 & 6.95 & 4.26 & 2.21 \\
\hline Lr5 & 3.03 & 1.71 & 0.77 & 1.38 & 0.46 & - & 1.32 \\
\hline Lr6 & 1.15 & 1.77 & & 0.02 & - & - & 1.1 \\
\hline Lr7 & - & - & - & - & - & - & 3.84 \\
\hline Mean ratio & 2.44 & 1.93 & 2.29 & 1.63 & 2.8 & 2.56 & 2.20 \\
\hline \multicolumn{8}{|l|}{$\begin{array}{c}\text { Bifurcation } \\
\text { ratio }(\mathrm{Rb})\end{array}$} \\
\hline $\mathrm{Rb} 1$ & - & - & - & - & - & - & \\
\hline $\mathrm{Rb} 2$ & 4.73 & 4.67 & 4.93 & 6.19 & 4.68 & 2.67 & 4.90 \\
\hline $\mathrm{Rb} 3$ & 4.81 & 4.09 & 4.47 & 4.46 & 4.38 & 4.00 & 4.43 \\
\hline $\mathrm{Rb} 4$ & 4.20 & 5.50 & 7.50 & 2.60 & 4.33 & 3.00 & 4.35 \\
\hline $\mathrm{Rb} 5$ & 2.50 & 2.00 & 2.00 & 2.50 & 3.00 & & 2.50 \\
\hline Rb6 & 2.00 & 2.00 & - & 2.00 & - & - & 2.67 \\
\hline $\mathrm{Rb} 7$ & - & - & - & - & - & - & 3.00 \\
\hline Mean Rb & 3.65 & 3.64 & 4.72 & 3.55 & 4.10 & 3.22 & 3.64 \\
\hline
\end{tabular}


Table 2. Aerial aspects of Gilgit Basin (GB) and sub-basins.

\begin{tabular}{|c|c|c|c|c|c|c|c|}
\hline Parameters & B1 & B2 & B3 & B4 & B5 & B6 & $\begin{array}{l}\text { Gilgit } \\
\text { Basin }\end{array}$ \\
\hline Area $\left(\mathrm{km}^{2}\right)$ & 3510.14 & 2860.3 & 2247.4 & 2388.5 & 2091.4 & 440.6 & 13,538 \\
\hline $\begin{array}{c}\text { Drainage } \\
\text { density (Dd) }\end{array}$ & 0.48 & 0.50 & 0.48 & 0.4 & 0.46 & 0.35 & 0.50 \\
\hline $\begin{array}{c}\text { Stream } \\
\text { frequency }(\mathrm{Fs})\end{array}$ & 0.17 & 0.19 & 0.18 & 0.17 & 0.16 & 0.11 & 0.18 \\
\hline $\begin{array}{l}\text { Form factor } \\
\text { ratio }(\mathrm{Ff})\end{array}$ & 0.24 & 0.50 & 0.79 & 0.84 & 0.36 & 0.50 & 0.481 \\
\hline $\begin{array}{l}\text { Circulation ratio } \\
\text { (Cr) }\end{array}$ & 0.25 & 0.32 & 0.44 & 0.41 & 0.26 & 0.50 & 0.231 \\
\hline $\begin{array}{l}\text { Elongation ratio } \\
\text { (Er) }\end{array}$ & 0.55 & 0.80 & 0.94 & 0.97 & 0.73 & 0.79 & 0.76 \\
\hline $\begin{array}{l}\text { Length of } \\
\text { overland flow } \\
\text { (Lo) }\end{array}$ & 1.04 & 1 & 1.04 & 1.04 & 1.08 & 1.43 & 1.02 \\
\hline $\begin{array}{c}\text { Drainage } \\
\text { Texture (Dt) }\end{array}$ & 1.44 & 1.61 & 1.65 & 1.61 & 1.07 & 0.46 & 2.79 \\
\hline
\end{tabular}

decrease with increase in stream order. The number of streams $\left(\mathrm{N}_{\mathrm{u}}\right)$ in each order is presented in Table 1 . The total 2390 stream lines are identified in the entire Gilgit river basin, out of which $78.9 \%$ (1886) is $1^{\text {st }}$ order stream, $16.1 \%(385)$ $2^{\text {nd }}$ order, $3.6 \%(87) 3^{\text {rd }}$ order, $0.837 \%(20) 4^{\text {th }}$ order, $0.335 \%(8) 5^{\text {th }}$ order, $0.126 \%$ (3) and 0.042 comprises $7^{\text {th }}$ order stream (1). During the calculation, it is noticed that the number of streams gradually decrease with increasing stream order Figure 3 and Figure 4.

\subsection{Stream Length (Lt) and Stream Length Ratio (Lr)}

According to Horton (1945), stream length refers to total length of stream segments in each consecutive orders. Stream length measures the average or mean length of a stream in each orders, and can be calculated by dividing the total length of all streams in an individual order by the number of streams in that order [3] If the bedrock and formation is permeable than small number of relative longer streams are formed, while a large number of streams of smaller length are developed where the bedrocks and formation are less permeable [16]. The result of order-wise stream length of Gilgit Basin and sub-basins as listed Table 1. Total streams length of Gilgit Basin $1^{\text {st }}$ order $3253.54 \mathrm{~km}, 2^{\text {nd }}$ order $1601.9,3^{\text {rd }}$ order $846.7 \mathrm{~km}, 4^{\text {th }}$ order $429.3 \mathrm{~km}, 5^{\text {th }}$ order $227.14 \mathrm{~km}, 6^{\text {th }}$ order $93.79 \mathrm{~km}$ and $7^{\text {th }}$ order has $120 \mathrm{~km}$. The order wise total streams length of sub-basin B1, B2, B3, B4, B5 and B6 are $1682.44 \mathrm{~km}, 1436.70 \mathrm{~km}, 1078.8 \mathrm{~km}, 1141.74 \mathrm{~km}, 957.08 \mathrm{~km}$ and $156.04 \mathrm{~km}$ respectively. Horton $(1945$, p. 291$)$ states that the length ratio is the ratio of the mean $(\mathrm{Lu})$ of segments in order to mean the length of segments of the next lower order $(\mathrm{Lu}-1)$, which tends to be constant throughout the successive orders of a basin. The stream length ratio of B1, B2, B3, B4, B5 and B6 are 


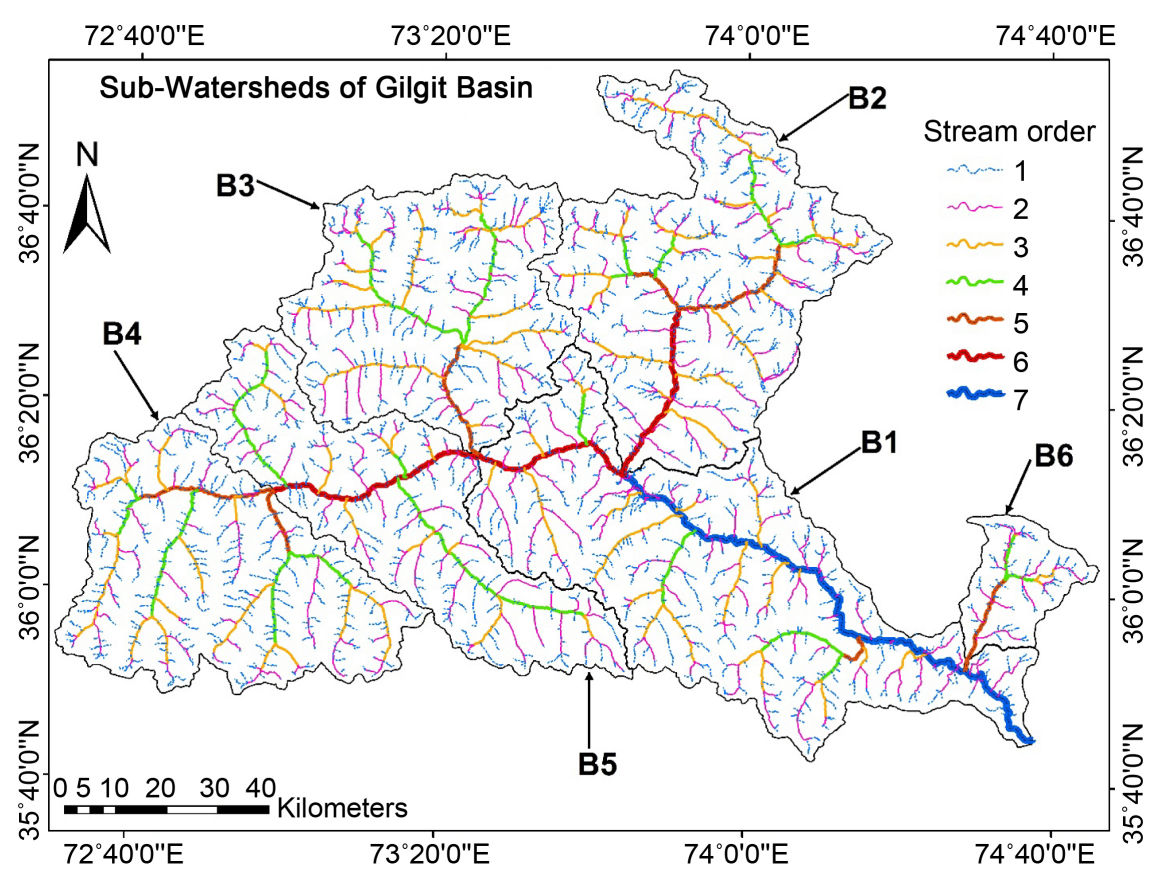

Figure 3. Drainage network of Gilgit and its sub-basins (threshold 2000).

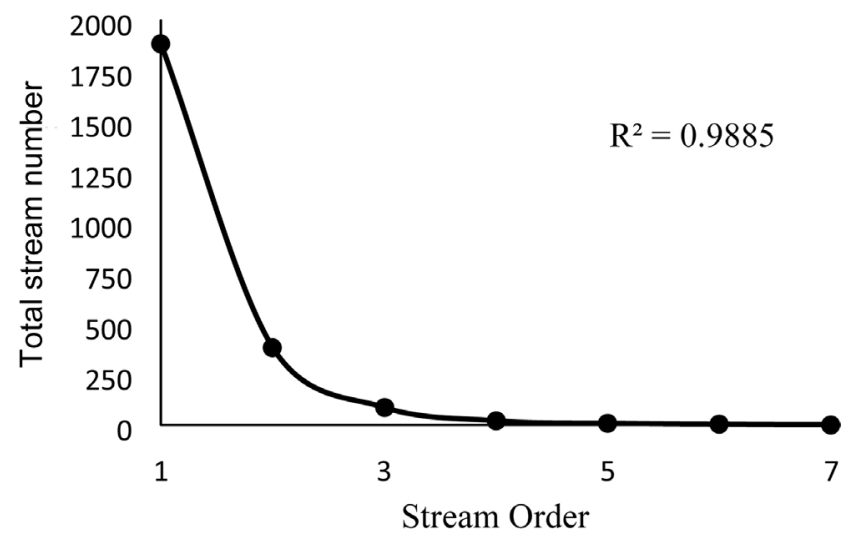

Figure 4. Relation between stream order and stream number.

$2.44,1.93,2.29,1.63,2.8$ and 2.56 respectively. The results reveal that the Gilgit Basin and sub-basins bedrocks and surface materials are less permeable.

\subsection{Bifurcation Ratio $\left(\mathbf{R}_{\mathbf{b}}\right)$}

River networks have been analyzed in terms of the number of branches ordered according to a system proposed by Horton (1945) and modified by Strahler (1957). The ratio among the number of stream segments in one order and the next called the bifurcation ratio, and this quantitative ratio determines drainage network which exists in the form branches. It is a dimensionless property and shows the degree of integration prevailing between streams or various orders in a drainage basin. According to Horton (1945), the bifurcation ratio varies from a minimum of 2 in "flat or rolling drainage basins" and 3 or 4 in "mountainous or highly dissected drainage basins". The bifurcation ratio range between 3.0 - 5.0 
indicates substantial structural control on drainage basin. The mean $R_{b}$ value of the Gilgit Basin is 3.64, while sub-basins $R_{b}$ values ranges between 3.22 - 4.72, which falls within the stipulated range of natural drainage system as suggested by Horton and Strahler $(1945,1957)$. It was observed from the $R_{b}$ values (Table 1) the Gilgit Basin and sub-basins influenced by structural control, couple with high relief and slope and also high overland flow due to hilly nature of terrain.

\subsection{Stream Frequency (Fs)}

The drainage frequency introduced by Horton (1932 and 1945), which is directly connected to the lithological characteristics. The number of stream fragments per unit area is called stream frequency or drainage frequency. A high stream frequency characterized by high surface runoff, steeper surface, impermeable subsurface material, spare vegetation and high relief setting. The stream frequency of Gilgit Basin is 0.18 per $\mathrm{km}^{2}$ while Fs of 6 basin vary from 0.19 to 0.11 . It was observed from the Fs values (Table 2) of Gilgit Basin and sub-basins has influenced by geology, high relief, steep slope and impermeable sub-surface material. Gilgit Basin and sub-basins contained many fingertip tributaries per unit area. Figure 5, the regression trend between drainage density and stream frequency. It shows a positive linear correlation. Fs values of the sub-basins have a close correlation with Dd indicating the increase in stream population with respect to increase in drainage density.

\subsection{Drainage Density (Dd)}

The main geometrical property of stream network is drainage density, which is the average length of channel per unit area of the basin. The poorly drained basin has a drainage density 2.74 , while well drained has 0.73 . Drainage density is ameasure of how frequently streams occur on the land surface. It reflects a balance between erosive forces and the resistance of the ground surface. It is closely related to climate, lithology, and vegetation. In drainage density analysis, inter-

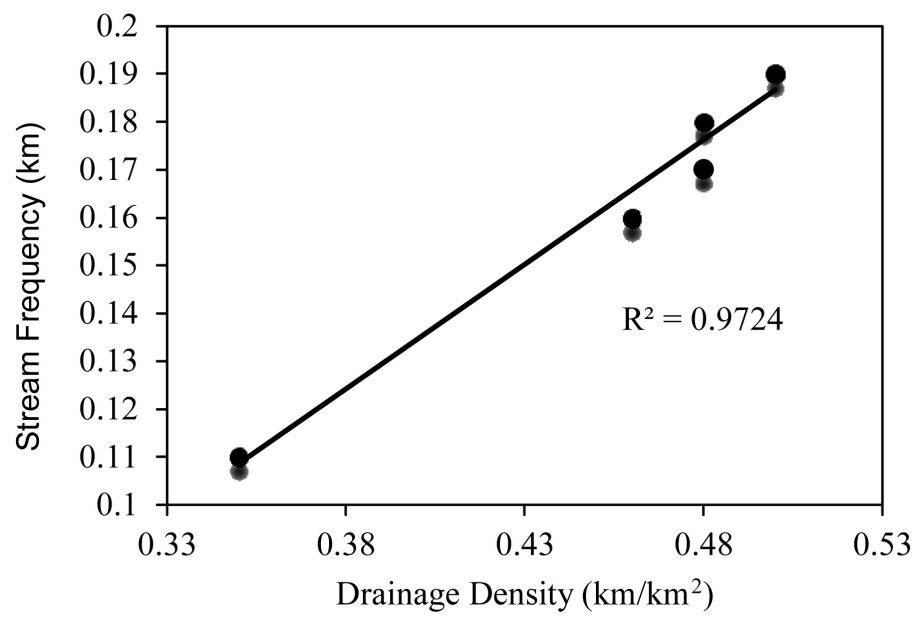

Figure 5. Relation between drainage density of the sub-watershed and stream frequency. 
mittent and ephemeral streams should be incorporated, because most of them performed during floods and bring flood water [1] [12] [17]. Gilgit Basin has a Dd value $0.50 \mathrm{~km} / \mathrm{km}^{2}$, which indicate a well-drained basin Figure 6. It was observed from the Dd values (Table 2) that the sub-watersheds of Gilgit river catchment are well-drained and Dd values are much closer with each other. High drainage density of the basin reveals that the basin surface is impermeable, spares vegetation and high relief. The drainage density map developed with the help of a focal statistics tool in ArcGIS spatial analyst. The drainage density map reveals that the very high $\mathrm{Dd}$ area is $7.6 \%, 20 \%$ area fall in high Dd, while $30 \%$ area is under moderate $\mathrm{Dd}$ and remaining covered by dried area.

\subsection{Form Factor (Ff)}

The form factor ratio is a dimensionless ratio of the basin area to the square of basin length. Form factor is the geometric index commonly used to characterize shapes of different basins. The value of form factor is in range, from $0.1-0.8$ [1] [2]. Lesser the value of form factor, more elongated will be the basin. The basins with high form factors 0.8 , have high peak flows of shorter duration, whereas, elongated drainage basin with low form factors have a lower peak flow of longer duration. The form factor of the Gilgit Basin is 0.48 and the sub-basins values range between $0.24-0.84$ Table 2. The basin B3 and B4 show high values of form factor, 0.78 and 0.84 are circular type basins. The basin B1 and B5 showlow values, 0.25 and 0.36 are elongated shape (Figure 7). Flood flows in elongated basins are easier to manage than the watersheds developed towards rectangular to circular shape such Phunder and Yasin basin. The morphological characteristics of a watershed have powerful impacts on watershed hydrology.

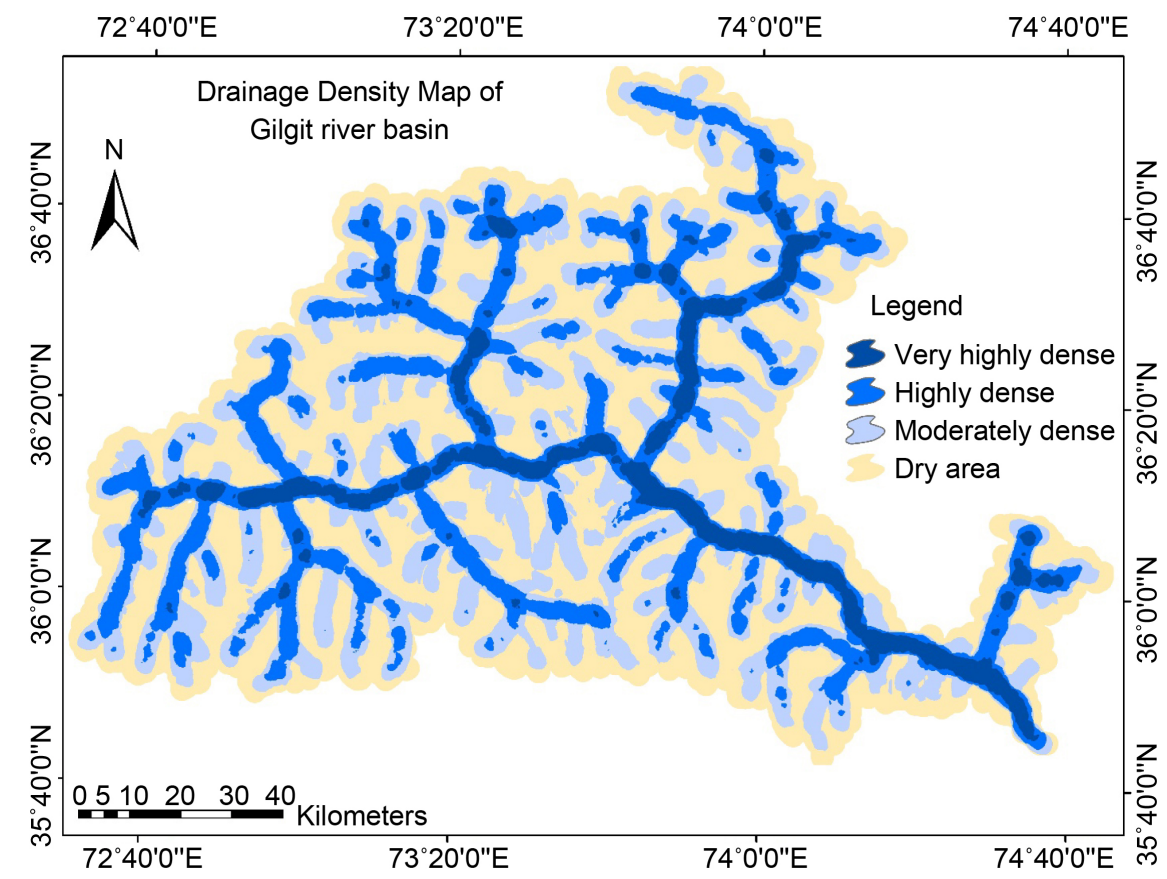

Figure 6. Drainage density map of the study area. 

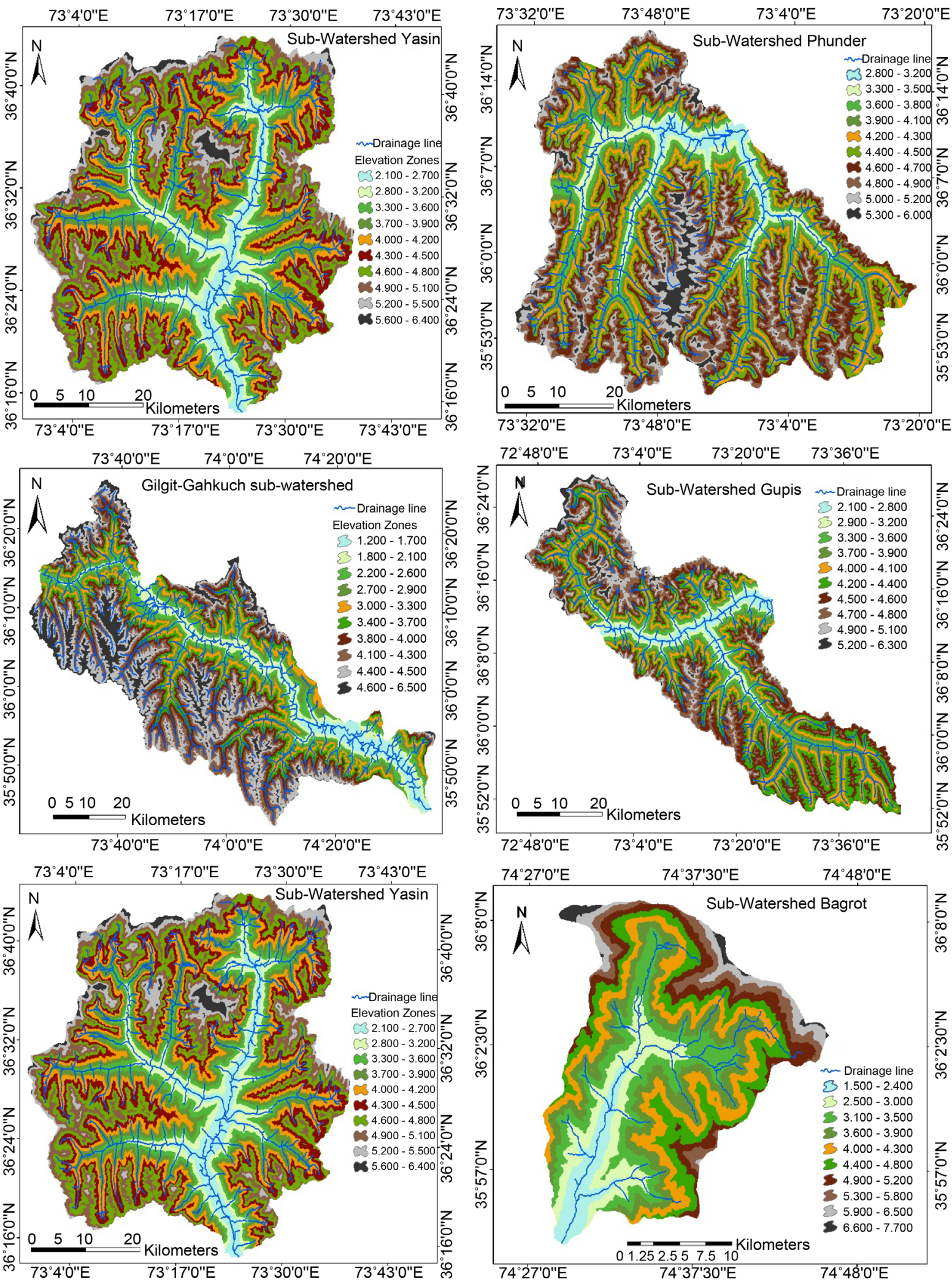

Figure 7. Drainage network and elevation zones of delineated 6 sub-basins of the study area.

\subsection{Circulation Ratio (Cr)}

The circularity ratio is a dimensionless parameter which shows a quantitative 
index of the shape of the basin. According to Miller (1953), circulation ratio is the ratio of the area of the basins in the area of a circle having the same circumference as the perimeter of the basin. Circulatory ratio is influenced by the lithology of the basin, stream frequency and gradient of various orders [3]. Gilgit Basin has $\mathrm{Cr}$ value 0.232 , whereas in 6 sub-basins have the value range between $0.24-0.51$ Table 2 . The circulation ratio results reveal that there is strong structural control on drainage development. It is seem that the structural control is probably responsible for the low values of circulation ratio.

\subsection{Elongation Ratio (Er)}

The elongation ratio expresses the shape of the drainage basin, which is the ratio of the diameter of the circle of the same area as the basin to maximum basin length [10]. This ratio usually runs from 0.6 to 1.0 in a broad range of climatic and geological setting. The Er values from 0.6 to 0.8 are associated with strong relief and steep group slope. The ratio gives an idea about the hydrological behavior or character of the basin such as circular basin is more efficient in the discharge of runoff than an elongated basin, whereas, time of concentration of runoff is less in elongated basin which leads peak runoff [18].

The elongation ratio of the Gilgit Basin is 0.76 while the sub-basins of values are range between $0.55-1$, which is less elongated basin with high relief (Table 2 and Table 3). The lower part of the Gilgit Basin is comparatively elongated with lower values than the upper and central area of the basin. In the study area, among the 6 sub-basins B2, B3 and B4 basins falls in less elongation category with the value range from $0.8-0.9$, while $\mathrm{B} 1, \mathrm{~B} 5$ and $\mathrm{B} 6$ show lower values and falls in elongated category (Figure 7).

\subsection{Length of Overland Flow (LOF)}

Hortonian overland flow happens when the rate at which rainfall surpasses the rate at which it can infiltrate into the soil. Their sustainability relies upon a supply of water from overland flow, through flow, interflow, base flow, and precipitation falling directly into the river. There are six independent variables which govern surface runoff phenomena such as rain intensity, infiltration capacity, length of overland flow, slope, surface roughness factor and type of overland flow Length. These factors are very important independent variables affecting both hydrologic and physiographic development of drainage basins [1] [19]. Gilgit Basin has LOF value of $1.03 \mathrm{~km} / \mathrm{km}^{2}$ while all other sub-basins values range between $1.04-1.43$, as shown in Table 2. The LOF of the basin is mod-

Table 3. Strahler (1964) classified elongation ratio.

\begin{tabular}{cc}
\hline$<0.7$ & Elongated \\
$0.8-0.7$ & Less elongated \\
$0.9-0.8$ & Oval \\
$>0.9$ & Circular \\
\hline
\end{tabular}


erately high that indicates the basin encompasses of high relief, steep slope, young topography, snow melting (in summer) and rainfall enter into the stream very quickly. In streams up to 3rd order are surging through highly dissected and steep gradient mountainous terrain, which facilitates high overland flow and less water recharge into the subsurface and also ground water potential is low in these stream orders. The entire Gilgit river basin falls under mountainous terrain, most of the rainfall and snowmelt water is lost as surface runoff, without infiltrating into the subsurface, due to rapid overland flow on the steep gradient and impermeable lithology.

\subsection{Drainage Texture (Dt)}

Drainage texture is one of the essential parameter in morphometric study, which shows spacing of drainage lines. Drainage lines are frequent and more active over impermeable areas than the permeable [2]. The texture of a rock is commonly dependent upon underlying lithology, infiltration capacity, relief aspect, vegetation type and climate of the terrain. According to Horton (1945), infiltration capacity is an important factor which effects drainage texture, and it is considering that drainage texture has strong correlation with drainage density and stream frequency. Smith (1950) classified drainage texture as follows: $<2$ very coarse, 2 - 4 coarse, 4 - 6 moderate, 6 - 8 fine, $>8$ very fine. The drainage texture of entire 6 sub-basins are ranging from $0.46-1.65$ which reveals that very coarse drainage texture. The overall, drainage texture value of Gilgit Basin is 2.79 which indicates coarse drainage texture Table 3. It seems that the massive and resistant rocks and high relief have produced very coarse to coarse drainage texture basin.

\subsection{Ruggedness Number $\left(R_{N}\right)$}

Strahler's (1968) ruggedness number is the product of the basin relief and the drainage density and usefully combines slope steepness with its length. Raggedness number is used to measure the flash flood potential of the streams. Ruggedness number is the geometric characteristics of the basin and it is used to measure surface unevenness and also for assess the potential of flash flood in streams. Ruggedness number of Gilgit Basin is 3.83 and 6 sub-watersheds range 1.6 - 2.45. It was observed from the $\mathrm{R}_{\mathrm{N}}$ values (Table 4) of Gilgit Basin and sub-basins highly susceptible to soil erosion and having a complex structural control association with high relief and drainage density.

\subsection{Aspect}

The aspect refers to the direction a mountain faces; it pays a significant influence on its local climate, precipitation, snow melting, runoff generation, wind, vegetation, settlement and agriculture [20]. Slope aspect have a large influence on snowmelt rate and there for runoff potential. The aspect map of the Gilgit river basin is shown in Figure 8. North and Northeast covers 19.39\% area, North and Northwest covers $17.31 \%$ area. South and southeast aspect covers $24.8 \%$ area, whereas, Southwest covers $13.5 \%$ area and East aspect covers $24.7 \%$ area of the 
Table 4. Relief aspects of Gilgit river basin and sub-basins.

\begin{tabular}{cccccccc}
\hline Relief aspects & B1 & B2 & B3 & B4 & B5 & B6 & GB \\
\hline $\begin{array}{c}\text { Ruggedness } \\
\text { Number ( } \mathrm{R}_{\mathrm{N}} \text { ) }\end{array}$ & 1.89 & 2.45 & 2 & 1.6 & 1.9 & 2.08 & 3.83 \\
Relative Relief (ReRe) & 1.02 & 1.49 & 1.7 & 1.22 & 1.3 & 5.9 & 0.89 \\
Relief Ratio (ReRa) & 0.036 & 0.07 & 0.08 & 0.06 & 0.05 & 0.21 & 3.85 \\
Slope Degree (slopeD) & 2.06 & 3.79 & 4.60 & 3.68 & 3.10 & 11.79 & 2.21 \\
Slope Ratio (SlopeR) & 3.59 & 6.62 & 8.05 & 6.42 & 5.42 & 20.87 & 3.86 \\
\hline
\end{tabular}

basin.

\subsection{Slope}

Slope and elevation are two basic but distinct concepts in the study of landform. Slope is conceivably the most significant aspect of surface and surfaces are formed entirely of slopes. The slope may be defined as the perpendicular inclination between the hill top and valley bottom, stands with the straight line and expressed usually in degrees. The slope elements in any terrain controlled by climate and morphogenic processes operating in the underlying rocks [21]. The slope map of Gilgit Basin and a magnify portion of lower basin area presented in Figure 9 . The maximum area in steep slope category $\left(31^{\circ}-45^{\circ}\right)$ is $34.45 \%$ of the total angles followed by moderately steep slope i.e. $22.54 \%$. Minimum slope angles $11.55 \%$ area lie in the category of gentle slope $\left(>12^{\circ}\right)$. The moderate slope angle category lies in $\left(12^{\circ}-22^{\circ}\right)$ which covered $17.31 \%$ of the area. While very steep slope zone covers $14.15 \%$ of slope angles in the study area. The first zone is the innermost zone of the study area and has almost plane to the gentle slope of $<12^{\circ}$. In the moderate slope $\left(12^{\circ}-22^{\circ}\right)$ many valleys are situated. The moderately steep slope $\left(22^{\circ}-31^{\circ}\right)$ class characterized by fast flow of water, presence of boulders in the channel, steep sided cliffs, and erosional features are prominent in the area. A notable characteristic of steep and very slopes areas are covered by shrubs and vegetation, and it is not used for cropland, while these steep slope areas provide great opportunities for livestock rearing, In the steep slopes habitat for wildlife slopes provide travel corridors for many animal species in the area such as Eurasian lynx, Himalayan goral, Marco Polo sheep and marmotand snow leopard.

\subsection{Basin Relief Ratio}

Basin relief is the elevation difference of the highest and lowest point of the valley floor. The relief of Gilgit Basin is $6491 \mathrm{~m}$. The sub-basins relief range from 3302 to $6187 \mathrm{~m}$. North-west and south north of the basin shows comparatively high relief elevation. The relief ratio, (ReRa) is the ratio of maximum relief of horizontal distance along the longest dimension of the basin parallel to the principal drainage line. Relief ratio measures the overall steepness of a drainage basin and is an indicator of the intensity of erosion process operation on slope of the basin 


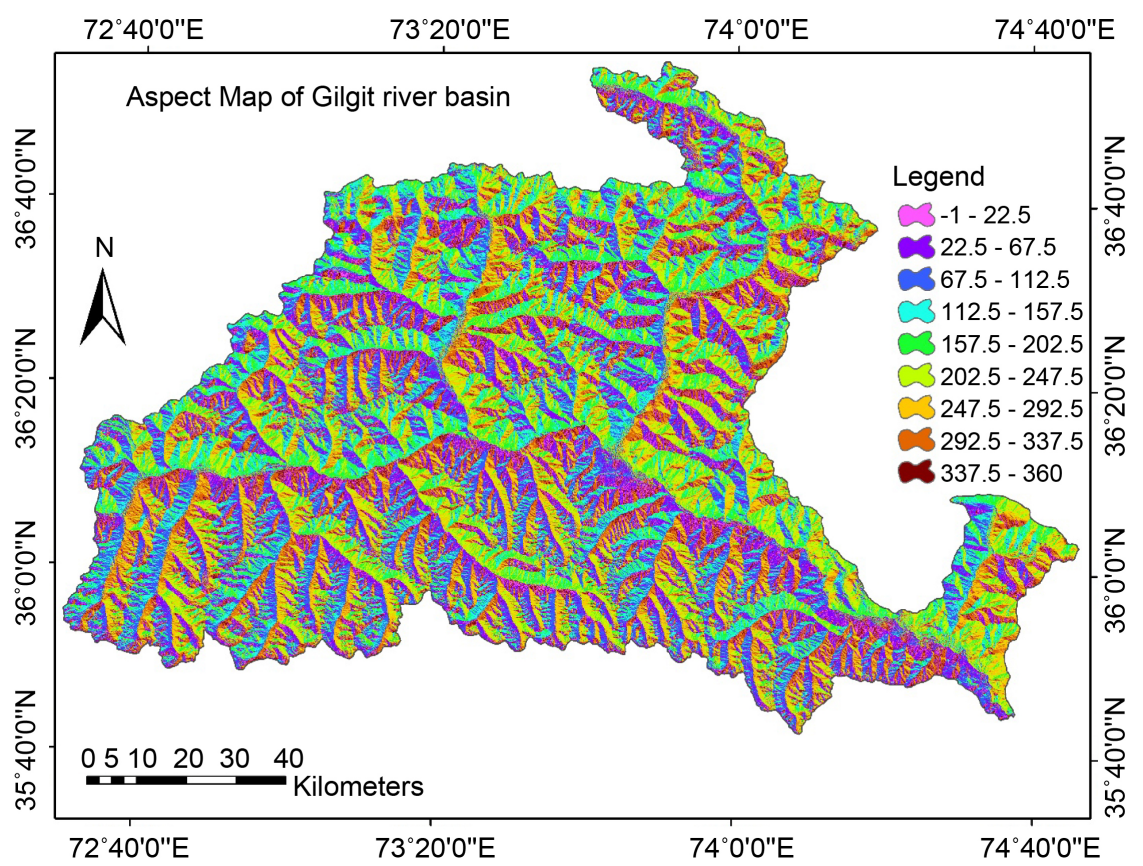

Figure 8. Aspect map of the study area.

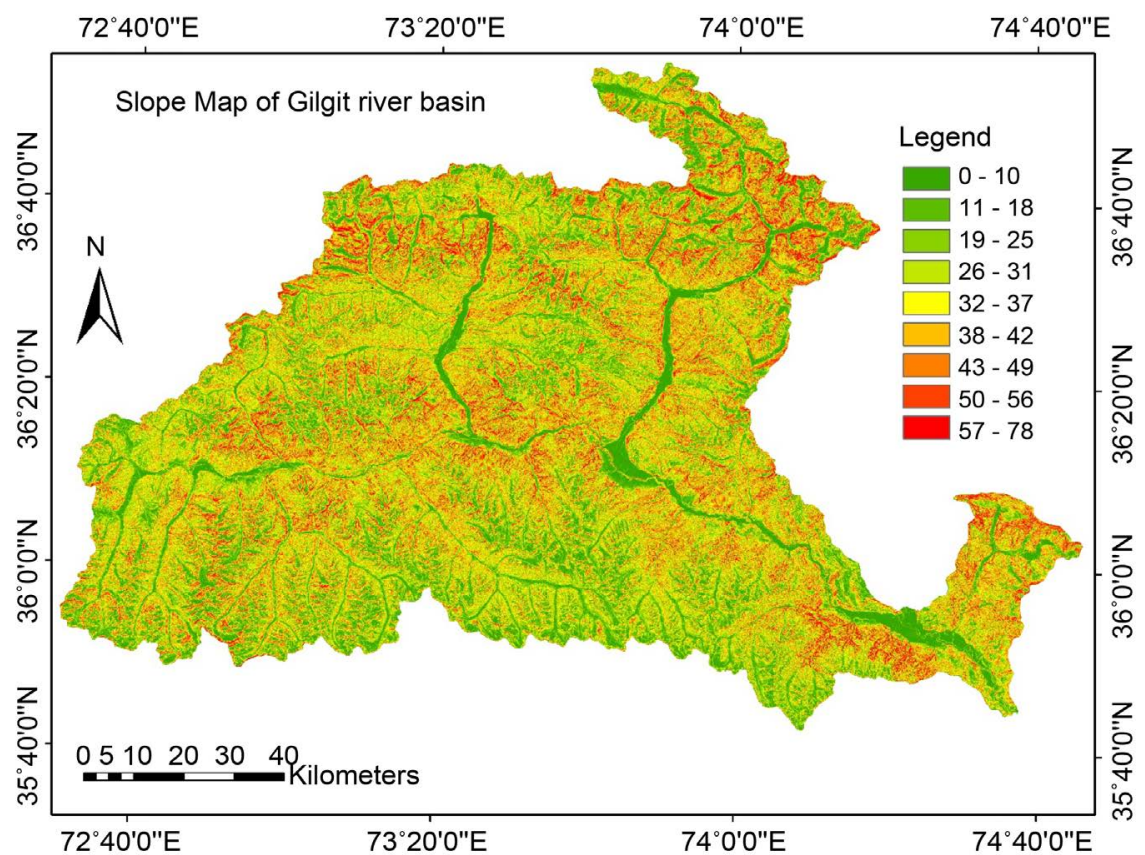

Figure 9. Slope map of the study area.

[10]. The relief ratio of the river Gilgit Basin is 0.041 while relief ratio of sub-basins varies from 0.036 to 0.21 (Table 4), it reveals that the basin is composed of resistant rocks, under intense relief and very steep slope.

\subsection{Relative Relief}

The Relative relief (ReRe) or local relief represents a variation of altitude in a unit area with respect to the local base level. It is an essential morphometric va- 
riable used for the comprehensive assessment of morphological characteristics of the terrain. The ReRe map of the basin is present in (Figure 10), which gives a clear picture of the nature and amount of local relief of the Gilgit Basin. The entire area is divided into six categories, such as; 1$)$ very low $\operatorname{Re} R e(1178-2260 \mathrm{~m})$, 2) low $\operatorname{Re} \operatorname{Re}(2260$ - $3342 \mathrm{~m})$, 3) moderately high $\operatorname{ReRe}(3342$ - $4424 \mathrm{~m})$, 4) high $\operatorname{Re} \operatorname{Re}(4424-5505 \mathrm{~m}), 5)$ very high $\operatorname{Re} R e(5505-6587 \mathrm{~m})$ and 6) extremely high ReRe (6587 - $7669 \mathrm{~m})$. The ReRe ratio of the Gilgit Basin is 0.89, whereas, subbasins ReRe values range between 1.02 to 5.9 (Table 4).

\subsection{Hypsometric Integral (HI)}

Hypsometry is a scientific term means the relative proportion of an area at various elevations within a region and the hypsometric curve portrays the distribution of area with reference to altitude. Hypsometric analysis can be used to understand and evaluate various forcing factors acting on basin topography. Hypsometric analysis gives valuable information on landform development and various types of erosive processes operating on the landscape [3] [22]. In the present study, the hypsometric integral was estimates using elevation-relief ratio method, proposed by Pike and Wilson (1971). It was observed from the HI values (Table 5) of Gilgit Basin is 0.48 which means $48 \%$ land still to be eroded and river basin is in between youthful to early mature stage of the cycle of erosion, whereas, sub-basins HI values were ranged between 0.410 .54 (Table 5). The results revealed that the soil erosion from these sub-basins was derived primarily from the cutting of channel beds, down slope movement of bedrock material and cutting of stream banks (Figure 11).

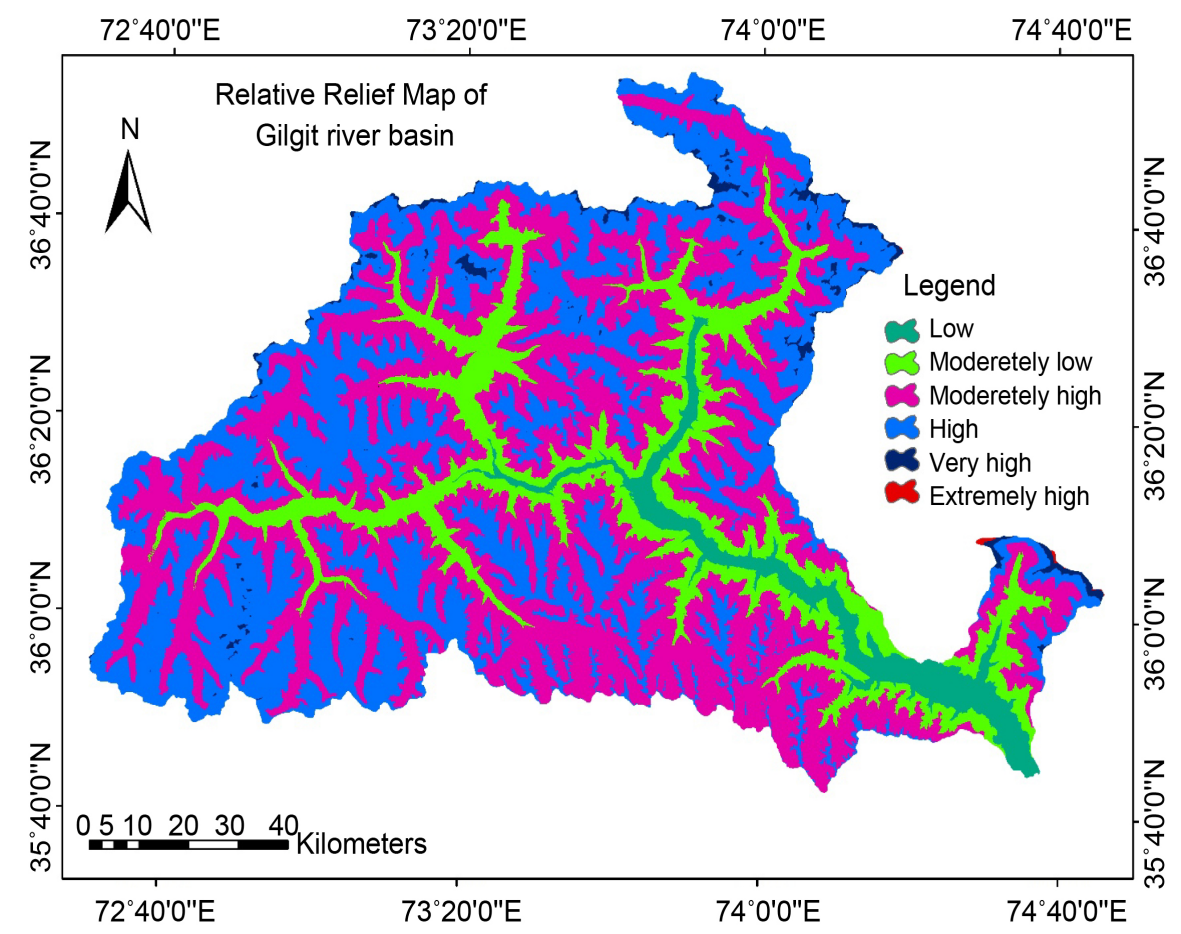

Figure 10. Spatial relative relief of Gilgit Basin. 
Table 5. Estimated hypsometric integral values of Gilgit Basin and sub-basins.

\begin{tabular}{cccc}
\hline Name of Basins & Area $\left(\mathbf{k m}^{2}\right)$ & $(\mathrm{HI})$ & Geologic stage \\
\hline B1 (Gilgit-Gahkuch) & 3510.14 & 0.54 & Late youthful/inequilibrium \\
B2 (Ishkoman) & 2860.3 & 0.46 & Mature/semi stabilized \\
B3 (Yasin) & 2247.4 & 0.46 & Mature/semi stabilized \\
B4 (Phunder) & 2388.5 & 0.53 & Late youthful/inequilibrium \\
B5 (Gupis) & 2091.4 & 0.49 & Late youthful/inequilibrium \\
B6 (Bagrot) & 440.6 & 0.40 & Mature/semi stabilized \\
Gilgit Basin & 13538 & 0.50 & Late youthful/inequilibrium \\
\hline
\end{tabular}

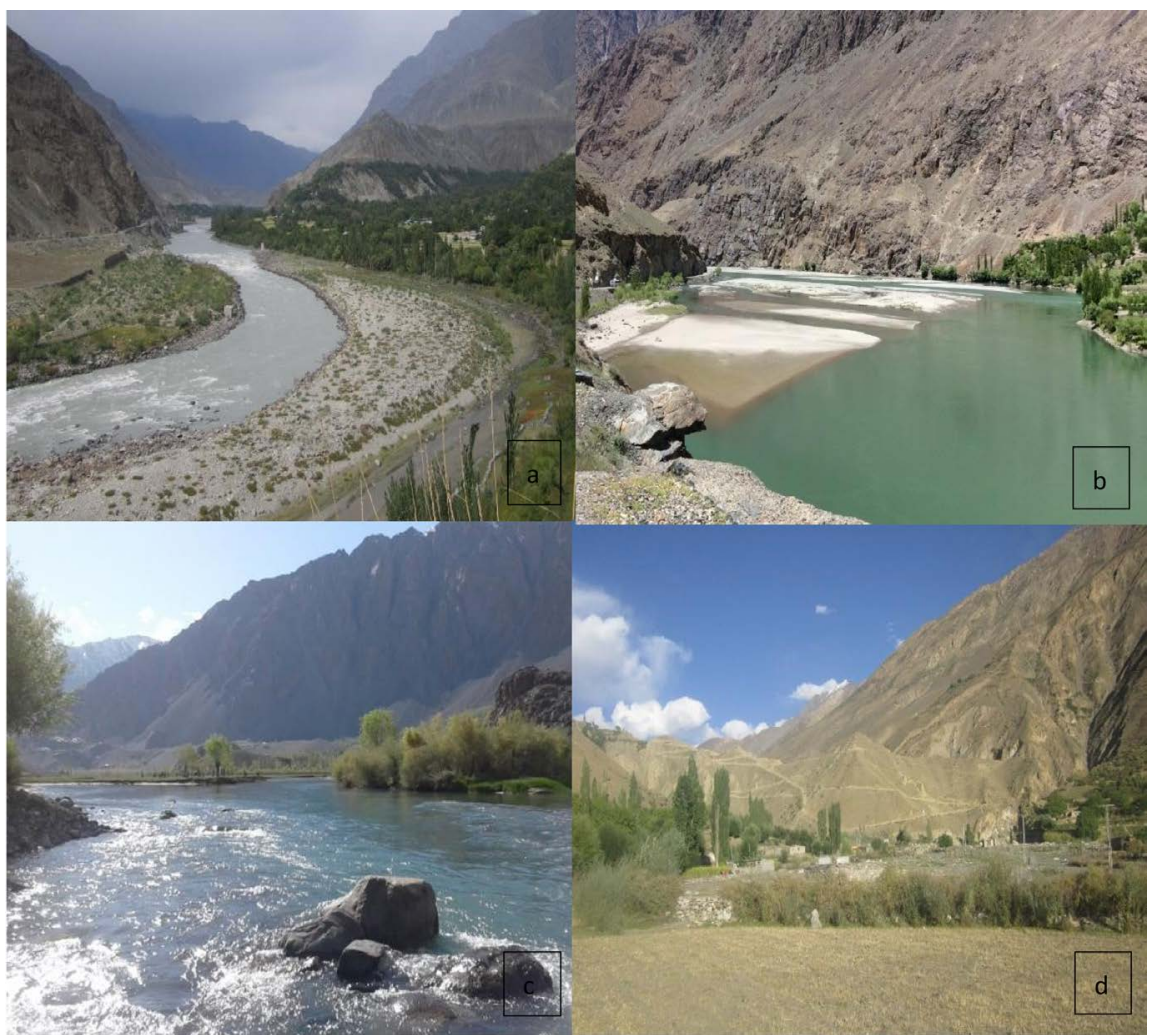

Figure 11. (a) Degraded land early matured landscape valley shereqila (b) land Eroded stream bank in the drainage channel (c) Phunder river flow towards Gilgit river (d) Intensive agricultural practices on the terraced land of Yasin sub-basin.

\section{Conclusion}

Morphometric analysis of drainage system is essential to any watershed related study. Gilgit river basin is located in the Hindu Kush and Karakoram mountains of Pakistan. Gilgit river basin is an important sub-basin of the upper Indus river basin. The study of Gilgit Basin morphometry successfully achieved by using ASTER DEM, Sentinel 2A image, coupled with geological and field data in the GIS environment. The entire basin is classified into six sub-basins, namely, Gilgit-Gahkuch (B1), Ishkoman (B2), Yasin (B3), Phunder (B4), Gupis (B5) and Bagrot (B6). The results of entire sub-basins shows dominated high relief, steep 
slope and youth to early mature fluvial geomorphic cycle. The first order streams are dominating in all the sub-basins, and drainage network with high number of lower order streams moving openly into higher orders.

Gilgit basin drainage density is $0.50 \mathrm{~km} / \mathrm{km}^{2}$, which indicates that the basin area has well drained and impermeable surface material. The mean $R_{b}$ value of the Gilgit Basin is 3.64, which falls within the stipulated range of natural drainage system as suggested by Strahler (1964). The values of stream frequency of the basin and sub-basins exhibit high impermeable geology, high relief and strong structural control on the drainage development. Gilgit Basin and sub-basins B2, B3, B4 are less elongated, while sub-basins B1, B5 and B6 reflect elongated shape. The ruggedness number is slightly higher for Gilgit Basin, which reveals high flash flood potential. The results of drainage texture indicate that the basin has coarse to very coarse texture. The hypsometry results indicate that the Gilgit Basin and sub-basins are in youthful stage towards the early mature stage.

\section{Acknowledgements}

Financial support for this research as part of the project "Sustainable Natural Resource Management for Climate Change Adaption" in the Himalayan region: A collaborative project among Norway, Nepal Pakistan and Bhutan. (Project No QZA-0485NPL13/0022), was provided by the NORHED program of NORAD.

\section{References}

[1] Horton, R. (1932) Drainage Basin Characteristics, Transactions. American Geophysical Union, 13, 350-361. https://doi.org/10.1029/TR013i001p00350

[2] Horton, R. (1945) Erosional Development of Streams and Their Drainage Basins, Hydrophysical Approach to Quantitative Morphology. Geological Society of America Bulletin, 56, 275-370. https://doi.org/10.1130/0016-7606(1945)56[275:EDOSAT]2.0.CO;2

[3] Strahler, A.N. (1952) Hypsometric Analysis of Erosional Topography. Bulletin of the Geological Society of America, 63, 1117-1142. https://doi.org/10.1130/0016-7606(1952)63[1117:HAAOET]2.0.CO;2

[4] A Quantitative Geomorphologic Study of Drainage Basin Characteristics in the Clinch Mountain Area, Virginia and Tennessee. Project NR 389042, Tech Report, Columbia University Department of Geology, ONR Geography Branch, New York.

[5] Gardiner, V. (1990) Drainage Basin Morphometry. In: Goudie, A., Ed., Geomorphological Techniques, Unwin Hyman, London, 71-81.

[6] Youssef, A.M., Pradhan, B. and Hassan, A.M. (2010) Flash Flood Risk Estimation along the St. Katherine Road, Southern Sinai, Egypt Using GIS Based Morphometry and Satellite Imagery. Environmental Earth Sciences, 62, 611-623. https://doi.org/10.1007/s12665-010-0551-1

[7] Kumar, R., Kumar, S., Lohni, A.K., Neema, R.K. and Singh, A.D. (2000) Evaluation of Geomorphological Characteristics of a Catchment Using GIS. GIS India, 9, 1317.

[8] Singh, O.P. (1976) Slope Studies of Palamsu Upland. A Quantitative Approach. Indian Geophysical Studies, Patna, Research Bulletin No. 6, 15-23. 
[9] Forkuor, G. and Maathuis, B. (2012) Comparison of SRTM and ASTER Derived Digital Elevation Models over Two Regions in Ghana-Implications for Hydrological and Environmental Modeling. In: Piacentini, T., Ed., Studies on Environmental and Applied Geomorphology, InTech, 219-240. https://doi.org/10.5772/28951

[10] Schumm, S.A. (1956) Evolution of Drainage Systems \& Slopes in Badlands at Perth, New Jersey. Bulletin of the Geological Society of America, 67, 597-646. https://doi.org/10.1130/0016-7606(1956)67[597:EODSAS]2.0.CO;2

[11] Melton, M.A. (1957) An Analysis of the Relations among the Elements of Climate, Surface Properties and Geomorphology. Technical Report 11, Department of Geology, Columbia University, New York.

[12] Chorley, R.J. and Kennday, B.A. (1971) Physical Geography: A System Approach. Longman Group Ltd., London, 369.

[13] Gregory, K.J. and Walling, D.E. (1973) Drainage Basin Form and Process: A Geomorphological Approach. Wiley, New York, 456.

[14] Sujatha, E.R., Selvakumary, R., Rajasimmanz, U.A.B. and Victorx, R.G. (2015) Morphometric Analysis of Sub-Watershed in Parts of Western Ghats, South India Using ASTER DEM. Geomatics, Natural Hazards and Risk, 6, 326-341. https://doi.org/10.1080/19475705.2013.845114

[15] Strahler, A. (1964) Quantitative Geomorphology of Drainage Basins and Channel Networks. In: Chow, V.T., Ed., Handbook of Applied Hydrology, McGraw-Hill, New York.

[16] Thomas, J., Joseph, S., Thrivikramji, K.P. and Abe, G. (2011) Morphometric Analysis of the Drainage System and Its Hydrological Implications in the Rain Shadow Regions, Kerala, India. Journal of Geographical Sciences, 21, 1077-1088.

[17] Macka, Z. (2001) Determination of Texture of Topography from Large Scale Contour Maps. Geography Bulletin, 73, 53-62.

[18] Singh, S. and Singh, M.C. (1997) Morphometric Analysis of Kanhar River Basin. National Geographical Journal of India, 43, 31-43.

[19] Huggett, R.J. (2007) Fundamentals of Geomorphology. 2nd Edition, Master e-book, New York

[20] Broxton, P.D., Troch, P.A. and Lyon, S.W. (2009) On the Role of Aspect to Quantify Water Transit Times in Small Mountainous Catchments. Water Resources Research, 45, W08427. https://doi.org/10.1029/2008WR007438

[21] Strahler, A.N. (1956) Quantitative Slope Analysis. Geological Society of America Bulletin, 67, 571-596. https://doi.org/10.1130/0016-7606(1956)67[571:qsa]2.0.co;2

[22] Vivoni, E.R., Di Benedetto, F., Grimaldi, S. and Eltahir, E.A.B. (2008) Hypsometric Control on Surface and Subsurface Runoff. Water Resources Research, 44, W12502. https://doi.org/10.1029/2008wr006931 
Submit or recommend next manuscript to SCIRP and we will provide best service for you:

Accepting pre-submission inquiries through Email, Facebook, LinkedIn, Twitter, etc. A wide selection of journals (inclusive of 9 subjects, more than 200 journals)

Providing 24-hour high-quality service

User-friendly online submission system

Fair and swift peer-review system

Efficient typesetting and proofreading procedure

Display of the result of downloads and visits, as well as the number of cited articles Maximum dissemination of your research work

Submit your manuscript at: http://papersubmission.scirp.org/

Or contact gep@scirp.org 